\title{
Allergic bronchopulmonary aspergillosis: still a mirage or ignorance
}

\author{
Surya Kant Tripathi, Rahul Srivastava, Ranganath Tg, Shipra Anand
}

Department of Pulmonary Medicine, CSM Medical University, Lucknow, Uttar Pradesh, India

Correspondence to Professor Surya Kant Tripathi, kantskt@rediffmail.com

\section{DESCRIPTION}

A 30-year-old female referred to our department as case of suspected multi-drug resistant tuberculosis with drug induced liver injury. She was on irregular antitubercular treatment (ATT) for past 2.5 years without improvement as prescribed by different physicians. Sputum examination for acid fast bacilli (AFB) was never done. Physical examination revealed bilateral polyphonic rhonchi. Sputum for AFB was negative on 2 consecutive days. Sequential x-ray showed typical fleeting shadows (figure $1 \mathrm{~A}-\mathrm{H}$ ). CT thorax revealed central bronchiectasis with toothpaste like hyper intense mucous impaction (figure 2A,B. Total serum IgE-2700 IU/ml, skin prick test for Aspergillus spp. was positive (figure 2C]. Final diagnosis 'Allergic bronchopulmonary aspergillosis' (ABPA). Prednisolone $0.5 \mathrm{mg} / \mathrm{kg}$ was given once daily, within 1 month patient's symptoms improved significantly. The patient was lost to followup and stopped treatment due to pregnancy and came back after 9 months with chest x-ray (figure $1 \mathrm{H}$ ) showing infiltrates on right side. ABPA is an immune mediated inflammatory syndrome caused by hypersensitivity to a fungus, Aspergillus fumigates. ${ }^{1}$ ABPA may mimic tuberculosis. $^{2}$ So diagnosis can be made on the basis of a combination of clinical, immunological and radiological findings but currently presence of high attenuation mucus is considered pathognomic of ABPA. ${ }^{3}$

\section{Learning points}

ABPA has five stages (acute, remission, exacerbation, glucocorticoid dependent and end stage fibrotic).

- If timely diagnosis and correct treatment is not given it can reach up to fibrotic stage. Looking up serial $x$-ray is very important for diagnosing patients.

- Chest infiltrates are not synonymous with pulmonary tuberculosis even in high burden countries like India.

- Bacteriological confirmation should be sought under most of the conditions before starting ATT.
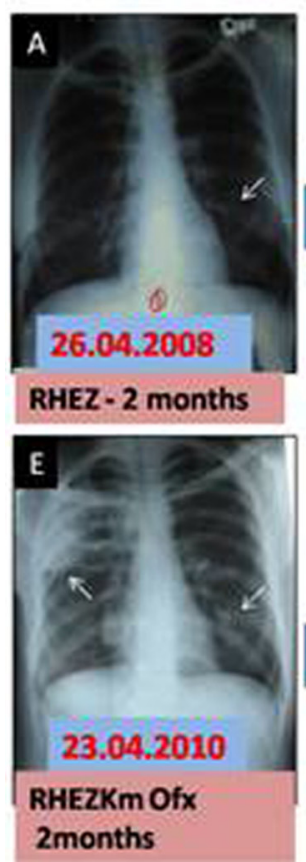
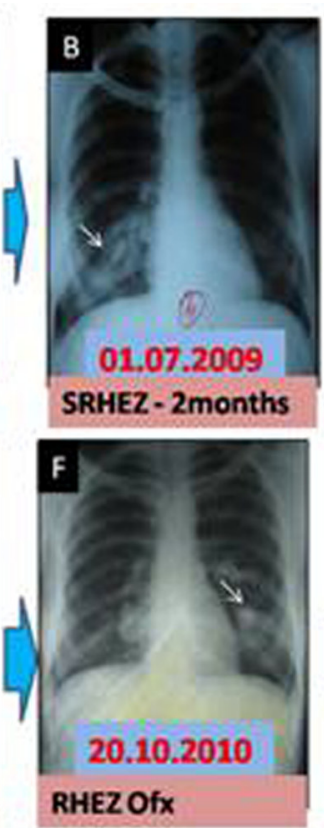

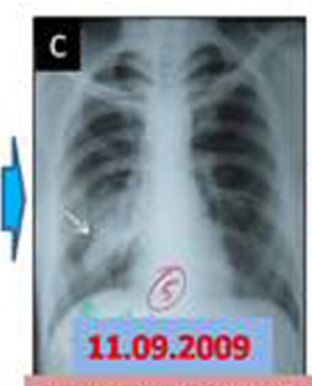

RHEZ Levo-5 months

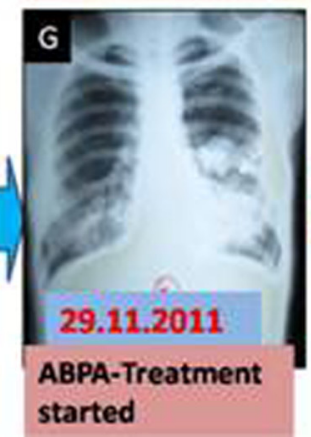

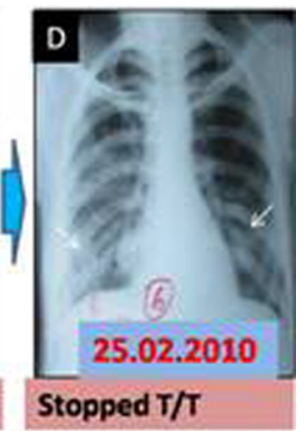

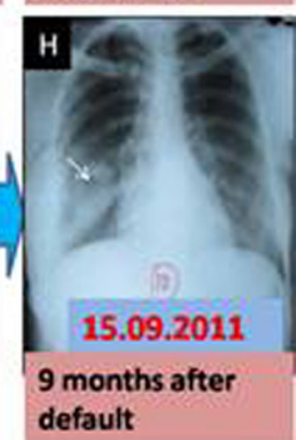

Figure 1 (A-H) Sequentially arranged radiographs showing fleeting shadows with antitubercular treatment taken and their duration. 


\section{BMJ Case Reports}
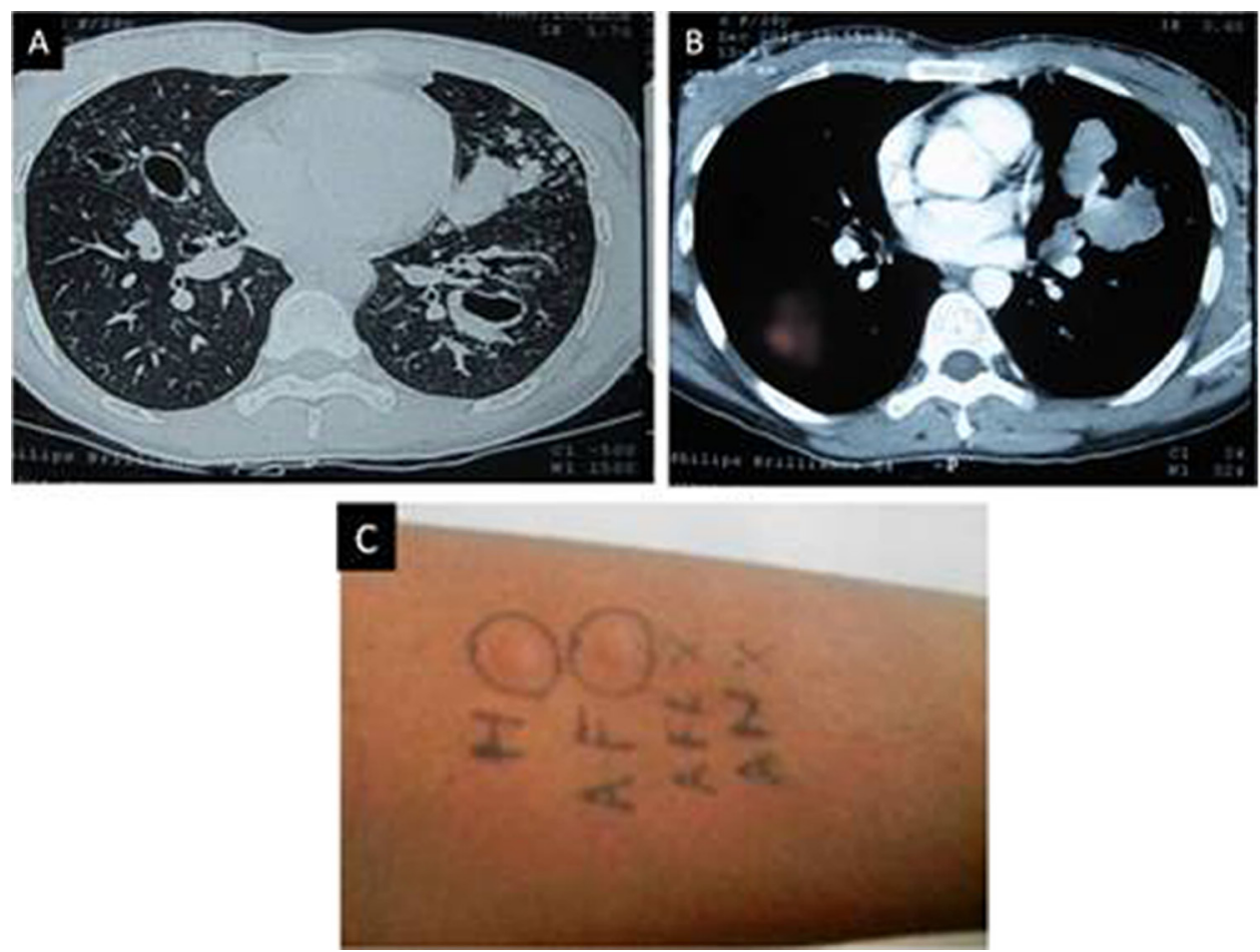

Figure 2 (A, B) Cystic bronchiectiasis with mucus impaction. (C) Skin prick test positive for Aspergillus fumigates.

Competing interests None.

Patient consent Obtained.

\section{REFERENCES}

1. Agarwal R. Allergic bronchopulmonary aspergillosis. In: Jindal SK, Shankar PS, Raoof S, Gupta D, Aggarwal AN, Agarwal R, eds. Textbook of Pulmonary and Critical Care Medicine. First Edition. New Delhi: Jaypee Publication 2010:947-70.

2. Kant S, Sanjay. Allergic bronchopulmonary aspergillosis mimicking as pulmonary tuberculosis. Lung India 2007:24:142-4.

3. Webb WR, Muller NL, Naidich DP. Airway diseases. High-Resolution CT of the Lung. Fourth Edition. Philadelphia, PA: LWW 2009:492-554.

This pdf has been created automatically from the final edited text and images.

Copyright 2012 BMJ Publishing Group. All rights reserved. For permission to reuse any of this content visit

http://group.bmj.com/group/rights-licensing/permissions.

BMJ Case Report Fellows may re-use this article for personal use and teaching without any further permission.

Please cite this article as follows (you will need to access the article online to obtain the date of publication).

Tripathi SK, Srivastava R, Tg R, Anand S. Allergic bronchopulmonary aspergillosis: still a mirage or ignorance. BMJ Case Reports 2012;

10.1136/bcr.01.2012.5584, Published XXX

Become a Fellow of BMJ Case Reports today and you can:

- Submit as many cases as you like

- Enjoy fast sympathetic peer review and rapid publication of accepted articles

- Access all the published articles

- Re-use any of the published material for personal use and teaching without further permission

For information on Institutional Fellowships contact consortiasales@bmjgroup.com

Visit casereports.bmj.com for more articles like this and to become a Fellow

Keep up to date with all published cases by signing up for an alert (all we need is your email address) http://casereports.bmj.com/cgi/alerts/etoc 